\title{
Kathryn Edgerton-Tarpley, Tears from Iron: Cultural Responses to Famine in Nineteenth- Century China
}

Pierre-Étienne Will

\section{OpenEdition}

\section{Journals}

Édition électronique

URL : http://journals.openedition.org/chinaperspectives/5354

DOI : 10.4000/chinaperspectives.5354

ISSN : 1996-4617

Éditeur

Centre d'étude français sur la Chine contemporaine

Édition imprimée

Date de publication : 15 décembre 2010

ISSN : 2070-3449

\section{Référence électronique}

Pierre-Étienne Will, « Kathryn Edgerton-Tarpley, Tears from Iron: Cultural Responses to Famine in Nineteenth-Century China », China Perspectives [En ligne], 2010/4 | 2010, mis en ligne le 15 décembre 2010, consulté le 23 septembre 2020. URL : http://journals.openedition.org/chinaperspectives/5354 DOI : https://doi.org/10.4000/chinaperspectives.5354

Ce document a été généré automatiquement le 23 septembre 2020

(c) All rights reserved 


\title{
Kathryn Edgerton-Tarpley, Tears from Iron: Cultural Responses to Famine in Nineteenth-Century China
}

\author{
Pierre-Étienne Will
}

1 Kathryn Edgerton-Tarpley, Tears from Iron: Cultural Responses to Famine in Nineteenth-Century China, Berkeley, University of California Press, 2008, xxiii + 332 pp., illustrations.

The “Incredible Famine of 1878-1879" (dingwu qihuang 丁戊奇荒), ${ }^{1}$ which devastated the northern provinces early in Emperor Guangxu's reign, may be said to have been China's first internationalised famine: it took place under other countries' gaze, it was much reported in Europe, and within China itself it came to be deemed a national shame because of the sorry spectacle it offered foreigners. The multiplicity of views and interpretations that famine sparked within and outside china is at the centre of this solid, undeniably original, and quite successful book - my only (slight) reservations being a certain penchant for sentimentality and an occasional overly didactical style, probably out of a desire to cater to the undergraduate market. Apart from a detailed account of the famine and its horrendous consequences in Shanxi Province, the book attempts a "cultural" history of the event by reviewing the extremely divergent and even contradictory perspectives of the victims of the catastrophe, of local officials, of the "modernisers" and traditionalists among the upper strata of the state, of the North China Herald and its self-important foreign readership in the Shanghai concessions, of missionaries on the ground, of leaders of new Buddhist philanthropy also centred in Shanghai, and of the Shenbao, which they used as their organ.

It is extremely difficult to piece together how ordinary people lived through the events. The sources are crammed with platitudes and rhetorical exaggerations, hence all sorts of problems of interpretation, which the author - I hasten to say - has in general been able to handle successfully. Such is the case, for example, with remembered accounts 
that she recorded from the field. Because of their very accuracy one is not sure what to think of these "reminiscences" told in the early 2000s by elderly Shanxi residents (the young seem no longer interested in the events), these "folk-tales" recorded from interviews with old men narrating what their grandparents had told them when they were little. However, Edgerton-Tarpley also got hold of accounts from periods closer to the events, such as an extensive "Song of the Famine Years" (Huangnian ge 荒年歌) composed some two decades later by a Xiezhou resident and said to have maintained local memory of the famine long afterwards, which she uses as a narrative thread in Chapter 2 and elsewhere. ${ }^{2}$ In the chapter on the causes of the catastrophe, the author says she interviewed 51 "local historians and village elders." What they have to narrate seems rather conventional, but it may be noted that they are not always in agreement, and while their debates depart from historical reality they still retain some interest. Also interesting is the fact that all of them speak very highly of Emperor Guangxu, even though he was only six years old when the famine started and the throne was able to do very little in his name. The salience of the model pitting the virtue and humanity of top leaders, from whom everything is sought, against the local authorities' indifference and sabotage, surely deserves noting.

4 At the same time, one never tires of admiring the continuity in discourse, interpretation, and even language when it comes to the causes and manifestations of famine, from Antiquity and often until today. We are treated to the usual considerations regarding the famine's moral causes, upright citizens and profiteers, honest officials and corrupt subalterns, the people's suffering, dispersed families, refugees dying of hunger by the roadside, and so on. But again, the author rarely allows herself to be taken in by these "idealised" anecdotes: on the contrary, she takes them apart and reaches beyond them. The entire third part of the book, "Images, Myths and Illusions," is devoted to such an effort.

5 Still, Edgerton-Tarpley may not always be aware of the antiquity of certain tropes and of the amount of terminology going back to the Classics. Guarding against famine by building up reserves is an obsession whose canonical expression, repeated like a mantra in the sources, harks back to the Book of Rites (Liji): "Out of three years of ploughing, conserve one year of supplies, out of nine years of ploughing, conserve three years of supplies” (三年耕必有一年之食, 九年耕必有三年之食). ${ }^{3}$ Viewing natural disasters as a heaven-sent punishment meted out to a dissolute society is also commonplace though it is not uninteresting that missionaries should have harped on this theme and extolling frugality as a precaution against disasters occurs in the oldest texts, not only since the eighteenth century (pp. 74-75). But what matters, of course, is that these notions had been deeply internalised by authors contemporary to the Guangxu famine and by so many of their successors.

6 As Chapter 4 recalls, senior leaders were far from agreed on what to do. Those favouring stronger maritime defences, headed by Li Hongzhang and the Zongli yamen, wanted the least amount of state resources diverted to Shanxi and its hungry masses, whereas the "Purification Party" (qingliu) activists, hewing closer to the Censorate and the Hanlin Academy, held that the most urgent need was to restore the legitimacy of the state and the dynasty, which had been badly damaged since the mid-nineteenth century, by means of mobilising the maximum of relief supplies. Alongside this controversy there was the debate - going back at least to the Song dynasty, not to the eighteenth century as the author seems to suggest (p. 103) - between letting merchants 
transport grain to famine areas as they saw fit and maintaining strict checks on them, or even keeping them out. And then there was the (much more recent) debate over opium: some favoured a total ban, holding that opium production was one of the main causes of famine conditions as it led to the neglect of food production (this is still a dominant notion today), while others - again, Li Hongzhang and foreign affairs experts - argued that the monopoly of opium production should not be left to foreigners as it was an important source of income for local people.

7 The commercialisation versus self-sufficiency debate is, of course, a classic one. Edgerton-Tarpley cites several accounts suggesting that on the eve of the "Incredible Famine," Shanxi (at any rate the hinterland of Taiyuan and the province's southern prefectures), far from being as miserable and isolated as usually described, was a prosperous region, almost an El Dorado where "luxurious customs" extended even to ordinary people. In fact this prosperity, probably less widespread than suggested by the sources cited, was in trade, manufacturing, and mining. It did not depend on agriculture, which had long ceased to feed the population and generate sufficient taxes to balance the provincial budget. How could even as catastrophic a drought as that of 1877-1879 lead to such a sudden reversal of fortunes, disrupt trade networks, destroy transport and mining industries, and turn Shanxi into a poor, isolated enclave for a long time thereafter? The book offers some explanations, such as the diversion of state resources to combat rebellion in the 1850s and 1860s and the disruption of the wellknown Shanxi merchants' networks - the latter due to the same reason and even more to the reorientation of Sino-Russian trade after the 1860 treaties. Still, that things failed to get back to normal seems intriguing, as is the fact that the considerable commercial wealth amassed since the early Qing appears to have been of little use during the calamity.

8 Another interesting aspect of the famine is its varying impact on people depending on age group, sex, and social class. A famine's social effects are by definition differential, but as the author recounts, the distinctions evaporate as crops begin to fail in succession, as all classes end up suffering one way or another and even profiteers find themselves in dire straits: that is par for the course (recall the descriptions of the late Ming major famines in Jiangnan, another rich and highly commercially area). It is above all in her descriptions of the different effects suffered by men and women that Edgerton-Tarpley has interesting things to say. One might think that when conditions became impossible and choices needed to be made, young women and girls would have been the first to be sacrificed. Chapter 7 contains many anecdotes of just such examples, where families in straitened situations try to adopt strategies based on "Confucian" values, above all filial piety (which explains why elderly mothers have a better chance of surviving). All these accounts stress the importance of upholding morality, with virtuous women starving themselves to death or committing suicide rather than jeopardise other people's survival, or worse, compromise family honour by abandoning their home in order to survive at the risk of losing chastity, that being the ne plus ultra.

9 But these are the "correct" accounts that notables and officials strove to carve on steles, inscribe in local monographs, and circulate among the populace. As shown by Edgerton-Tarpley, the reality reflected in more objective sources was less edifying than in such stories. Descriptions abound of women sold for a fistful of coins or abandoned by the roadside, ready to give themselves to the first comer in order to live, and whose 
usual fate was to end up in the hands of so-called "southern traders" who sold them on as concubines or prostitutes. Trafficking in women and the cynical and cruel treatment of women figure prominently in the denunciations in Shanghai's English language press and in the reformers' lamentations over "national shame." The book reproduces some gripping accounts by both European observers and Chinese philanthropists who had been in famine-struck areas and seen first-hand the desperate condition of women and young girls brutalised, raped, and treated as chattel.

Yet the book also shows that things were more complicated. Some studies on mortality suggest that being a woman could be an advantage during severe famines. Because of their relative scarcity, thanks to the practice of female infanticide, women were not sacrificed so easily, and penury was shared somewhat equally within families. Moreover, women were a form of capital: during famines their market value was greater than that of men. As for those who fell into traffickers' hands, they had perhaps a better chance of survival by being spirited out of famine areas. In short, as EdgertonTarpley notes, when faced with such tragedies, society functioned on a pragmatic mode far removed from Confucian schema - and I would add that it did so more or less in normal times too.

11 In the eyes of the most trenchant upholders of prevailing mores, the fact that a desperate woman should be ready to sell herself as a wife or servant in order to survive merely demonstrated the women's immorality or even the danger they posed, given that their misconduct was at times blamed for causing disasters. (Perhaps it was not essential to mention Queen Baosi and Yang Guifei here.) But some people had a more realistic view. We find in a late nineteenth century anthology of judicial decisions a case involving a certain Mme Xue who had fled the Shanxi famine in 1877 with her two adolescent children, probably with the consent of her husband, Mr. Zhang. She had ended up in northern Shaanxi where, after further misadventures, she had sold herself in marriage to a $\mathrm{Wu}$ family. The case concerned her feud with her mother-in-law nine years later (her new husband had died by then). I cite this because the magistrate, a comparatively well-known scholar-official named Fan Zengxiang 樊增祥 (1846-1931), noted in his judgment that $\mathrm{Wu}$ had had the best of reasons to flee the famine and remarry elsewhere rather than trying to "preserve her chastity" at all cost (even though it meant bigamy!): she not only escaped certain death, but thanks to her choice, her son remained alive to carry on the Zhang line. From this point of view at least, Fan did not find fault with her morality and did not shirk from calling her a "highly meritorious person" (gongchen功臣). Although she hardly wished it, he sent her back with her son to her original family in Shanxi. ${ }^{4}$ To be sure, this is no more than a footnote to the rich work of Edgerton-Tarpley; still, the contrast to the heartrending descriptions she cites, the calculated and effective way in which Madam Xue managed to survive the famine and rebuild her life seems to me worth mentioning.

12 There is much more that one can commend in this book, which contains many references to events outside China (the 1845-1849 Irish Famine being a favourite yardstick), and occasionally alludes to more recent ones in China. ${ }^{5}$ One might mention Edgerton-Tarpley's discussion of the emergence of the "new charity" born of the competition with Western philanthropy, where for the first time the entire society of one region of China went to the aid of another region. One should also mention the last chapter, which, after some perhaps non-indispensable considerations on Orientalism and semiotics, offers a clever analysis of cannibalism as metaphor - indeed, the 
metaphor par excellence of the "Incredible Famine" in twenty-first century Shanxi, as the extremely voluble elderly people met by Edgerton-Tarpley appear to have perfectly incorporated into their "memory" the propaganda put out during the Great Leap Forward, to the effect that cannibalism during the Guangxu famine represented "old society," whereas things were much better now. The Guangxu famine, in other words, was made into a sort of "frightening historical Other." Finally a word must be said of the importance accorded in the book to images among the panoply of representations of famine ${ }^{6}$ and the ingenious use to which they are put.

In short, all this shows Tears from Iron to be a book that will doubtless stand out on a subject that, for reasons that remain to be understood, appears to have become quite popular among historians in China and elsewhere.

\section{NOTES}

1. 1878 and 1879 (dingchou丁丑and wuyin 戊寅) were the worst famine years, but the drought that caused the famine started in 1876.

2. This sort of material was probably not rare. I myself found in the Xi'an Stele Forest Museum a "Ballade of the famine years" (Huangsui ge 荒歲歌) carved in stone, much shorter than the text cited in the book and pertaining to the same Guangxu drought in a county in Shaanxi.

3. See pp. 78, 227. Curiously, Edgerton-Tarpley interprets the formula as meaning "planting three [rows of grain] but saving one, or planting nine but saving three" (author's brackets).

4. See Fanshan pipan 樊山批判, in Lidai panli pandu歷代判例判牘 (Beijing: Zhongguo shehui kexue chubanshe, 2005), vol. 11, pp. 609-610.

5. Basically the Great Leap Forward famine, which is the natural point of comparison for those questioned today. However, North China suffered other "incredible famines" that were also compared with the one in Guangxu (and said to be worse): one thinks especially of the great North China famines of the early and late 1920s, when China became known as a "land of famine" (China, Land of Famine, the influential book by Walter H. Mallory, appeared in 1926).

6. Notably compilations of prints entitled tielei tu 鐵淚圖, a phrase that Edgerton-Tarpley translates as "pictures to draw tears from iron" - hence the book's title - which by itself makes not much sense. The author of one of the first such books, the Jiangnan tielei tu (devoted to the destruction caused by the Taiping wars), explained that the horrors depicted in the text and illustrations are such that "seeing them, even an iron man would give way to tears" (所謂鐵人見 之，亦當墮淚也). 